\title{
IN SITU DETECTION OF HA-RAS AND C-MYC mRNA IN CANCER CELL LINES AND TISSUE SECTIONS OF COLORECTAL CANGER USING SULFONATED DNA PROBES
}

\author{
Takushi MONDEN, Hideki MORIMOTO, Masahiko higashiYaMa, \\ Masahiro MUROTANI, Naohiro TOMITA, Takashi SHIMANO, \\ Hiroshi OKUDA and TAKEsada MORI
}

\author{
Department of Surgery II, Osaka University Medical School, Fukushima 1-1-50, \\ Fukushima-ku, Osaka 553
}

\begin{abstract}
We have previously reported the technique of in situ hybridization utilizing sulfonated DNA probes for the detection of amylase mRNA in formalin-fixed paraffin sections of human pancreas and submaxillary gland (22). Using this technique, we detected the mRNAs of Ha-ras and c-myc oncogenes in colonic cancer tissues from 24 patients, as well as in cultured cell lines. HL 60 cells, which are known to have amplified c-myc gene and accelerated transcription rate of this gene (11), and transformed NIH/3T3 cells with T24 Ha-ras were hybridized in situ with the sulfonated DNA probes of $\mathrm{v}$-myc and v-Ha-ras respectively. Specific hybridization of v-myc probe for HL 60 and of $\mathrm{v}$-Ha-ras probe for NIH/3T 3 cells were clearly demonstrated at the cytoplasm by immunohistochemistry using a monoclonal antibody raised against sulfonated DNA. Of the colonic cancer tissues, which were freshly prepared and processed in paraffin, 6 were positive for Ha-ras mRNA and 7 were positive for c-myc mRNA. Northern blot analysis of the positive cases confirmed the validity of the results of in situ hybridization.
\end{abstract}

Several reports have demonstrated the amplification $(3,20,21)$ or increased expression of ras and/or myc concogenes in colorectal cancer. Over expression of c-Haras and/or c-myc oncogenes has been confirmed by Northern blot analysis $(2,7,23$, 24) or immunological techniques using antibodies raised against oncogene products $(8,10,15-18,24,28,29,32)$.

Northern blot or immunoblot analysis, however, represents the average of heterogeneous cell populations including many normal mesenchymal cells as well as cancer cells, and it is not possible to elucidate the increased expression of a reference oncogene in individual cells.

Thus, the immunohistological detection of oncogene products seems to provide much more valuable information especially for pathological researchers. Recently, several monoclonal antibodies have been raised against synthetic peptides encoded by Ha-ras or c-myc oncogene $(14,16,26,27)$. The results of immunohistological studies from independent laboratories using such monoclonal antibodies, however, have not always been consistent, and different patterns of oncogene expression have been described $(8,15-18,24,29,32)$. The reason for the disagreement is obscure, but monoclonal antibodies raised against a very small part of antigen molecule may recognize the unrelated proteins having a similar tertiary structure.

The mRNA-DNA in situ hybridization technique, which makes it possible to 
detect the gene transcripts in individual cells, is expected to provide a more direct proof of activation of the reference oncogene. In this experiment, we intended to detect Ha-ras and c-myc oncogene mRNAs in paraffin embedded tissue sections of colorectal cancer as well as in cultured cell lines using sulfonated DNA probes.

\section{MATERIALS AND METHODS}

Tissue samples

Small tissue samples obtained in endoscopic or romanoscopic examination of colorectal cancer were fixed immediately in $10 \%$ cold buffered formalin saline $\left(4^{\circ} \mathrm{C}\right.$, $\mathrm{pH}$ 7.4) for $2-3 \mathrm{hr}$. The tissues were rinsed with distilled water several times, dehydrated through graded ethanol, infiltrated and embedded in paraffin. Four micron thick sections were made on a poly-L-lysinecoated glass slide and dried at $40^{\circ} \mathrm{C}$ for $2 \mathrm{hr}$. The sections were then dewaxed in xylene, washed in absolute ethanol, air-dried and stored at $-20^{\circ} \mathrm{C}$.

For Northern blot analysis, $1 \mathrm{~cm}^{3}$ of tumor specimens and normal colon mucosae remote from the edge of cancer were collected from surgical specimens. The tissue specimens were immediately frozen and stored in liquid nitrogen until analyzed.

Cell preparation

NIH/3T3 cells were transfected with activated c-Ha-ras gene of T24 bladder carcinoma (pT22 clone) in our laboratory. The transformants were cultured on glass slides for $24 \mathrm{hr}$ in Dulbecco's minimal essential medium supplemented with $10 \%$ fetal calf serum (DMEM-10\% FCS), and the adherent cells were fixed in $10 \%$ cold buffered formalin saline $\left(4^{\circ} \mathrm{C}, \mathrm{pH} \mathrm{7.4}\right)$ for $5 \mathrm{~min}$. After dehydration, the samples were stored at $-20^{\circ} \mathrm{C}$ until used. A negative control of the untransformed NIH/3T3 cells was prepared in the same way.

A human promyelocytic leukemia cell line HL60 was obtained from the Japanese Cancer Research Resources Banak (JCRB; Tokyo, Japan) and cultured in DMEM$10 \%$ FCS. About $1 \times 10^{8}$ cells were centrifuged, pelletted, and fixed in $10 \%$ cold buffered formalin saline for $10 \mathrm{~min}$. Paraffin sections of HL60 cells were prepared as described above.

Preparation and sulfonation of the probes

A $0.88 \mathrm{~kb}$ Hind III fragment of Ha-MSV (13) (Takara Shuzo, Japan) and a $0.99 \mathrm{~kb}$ Sal I-Pst I fragment of MC29 (1) (v-myc; Takara Shuzo, Japan) were used as hybridization probes for in situ hybridization. A $0.95 \mathrm{~kb}$ Sau 3A I fragment of pUC 19 vector DNA was also prepared as a control probe. Sulfonation of DNA probes was carried out by treating denatured DNA with a mixture of bisulfite and o-methylhydroxylamine as described elsewhere (6).

In situ hybridization

The method for in situ hybridization was described previously (22). Briefly, sections were rehydrated, treated with $0.2 \mathrm{~N} \mathrm{HCl}$, heated to $65^{\circ} \mathrm{C}$ in $2 \times \mathrm{SSC}$, and digested with $5 \mu \mathrm{g} / \mathrm{ml}$ proteinase $\mathrm{K}$. After prehydridization for $4 \mathrm{hr}$, hybridization was carried out at $42^{\circ} \mathrm{C}$ for $12-18 \mathrm{hr}$ using sulfonated v-Ha-ras, v-myc or pUC 19 probes. After extensive washing in $2 \times \mathrm{SSC}$ at $37^{\circ} \mathrm{C}$ for several hours, specific hybridization signals were visualized immunohistochemically by the avidin-biotin peroxidase complex $(\mathrm{ABC})$ method using a monoclonal antibody specific to sulfonated DNA (Orgenics, Israel). 
Northern blot hybridization

Total cellular RNA was isolated from the tissues of colorectal cancer and normal colon mucosa essentially as described previously (9). The poly-A(t) RNA was purified from total RNA by repeated passages through an oligo dT cellulose column. An aliquot $(5 \mu \mathrm{g})$ of mRNA was electrophoresed in $1 \%$ agarose/2.2 M formaldehyde gel (19) and then transferred to a nylon filter (Gene Screen Plus, NEN, USA.). After hybridization with ${ }^{32} \mathrm{P}$-labeled $\mathrm{v}$-Ha-ras or $\mathrm{v}$-myc probe, the filter was exposed to $\mathrm{X}$ ray film (Kodak XA-5) overnight at $-70^{\circ} \mathrm{C}$.

\section{RESULTS}

When NIH/3T3 cells transfected with T24 Ha-ras were hybridized in situ with the sulfonated v-Ha-ras, the cytoplasms of almost all the cells were stained diffusely (Fig. 1a). The control study using the NIH/3T3 without transfection showed only weak staining (Fig. 1b), and hybridization with unrelated sulfonated probe pUC gave no visible staining. The Southern blot analysis of the T24 Ha-ras transfected NIH/3T3 cells showed that the DNA of the transfected cells contained more than 6 copies of Haras gene (data not shown). HL 60 cells, which are known to have a markedly amplified c-myc oncogene and accelerated transcription of this gene (11), were proved to have an accumulation of c-myc mRNA in the cytoplasm by sulfonated v-myc probe. In the case of HL 60, however, the staining pattern was heterogeneous, and some cells were not stained (Fig. 2).

Of 24 colorectal cancer tissue specimens, 6 stained positive for Ha-ras mRNA and 7 were positive for c-myc mRNA (Figs. 3a, b, 4). The cancer tissues examined were well or moderately differentiated, and one mucinous adenocarcinoma was included. In these cases, heterogeneity of staining intensity in the same section was observed by in situ hybridization (Fig. 3a).

Ten of the 24 colorectal cancer specimens were also examined by Northern blot

TABle 1. Results of in situ hybridization and Northern blot analysis of 10 cases of colorectal cancer

\begin{tabular}{cccccccc}
\hline \multirow{2}{*}{ Case No. } & \multirow{2}{*}{ Age } & \multirow{2}{*}{ Histol. } & \multicolumn{2}{c}{ Ha-ras mRNA } & & \multicolumn{2}{c}{ c-myc mRNA } \\
& & & ISH & NB & & ISH & NB \\
\hline 1. & 53 & Well & - & - & & + & + \\
2. & 60 & Well & - & - & & + & + \\
3. & 80 & Well & + & + & & - \\
4. & 50 & Muc & + & - & & + & + \\
5. & 37 & Mod & - & - & & - \\
6. & 58 & Well & - & + & & - & - \\
7. & 61 & Mod & - & - & & + \\
8. & 41 & Well & + & + & & + & N.T. \\
9. & 57 & Well & - & + & & N.T. & N.T. \\
10. & 75 & Well & + & + & & - & N.T. \\
\hline
\end{tabular}

ISH: in situ hybridization, NB: Northern blot analysis

N.T.: not tested. 


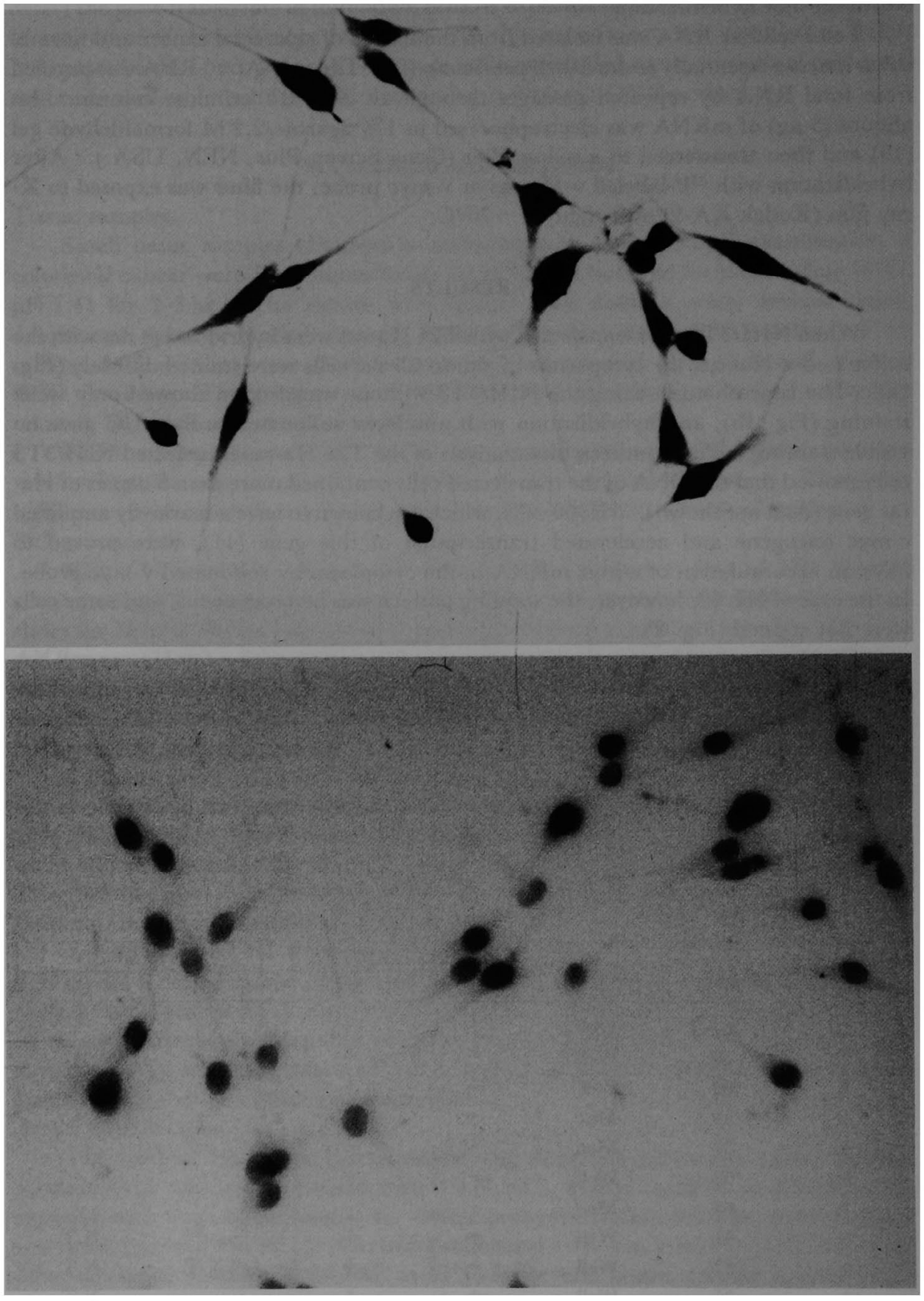

FIG. 1. In situ hybridization of sulfonated v-Ha-ras ( $880 \mathrm{bp})$ to the NIH/3T3 cells with or without transfection of T24 c-Ha-ras gene. The transfectant cells show diffuse staining of cytoplasms (a), but the cells without transfection give only weak staining (b). Counterstained with methylgreen. 


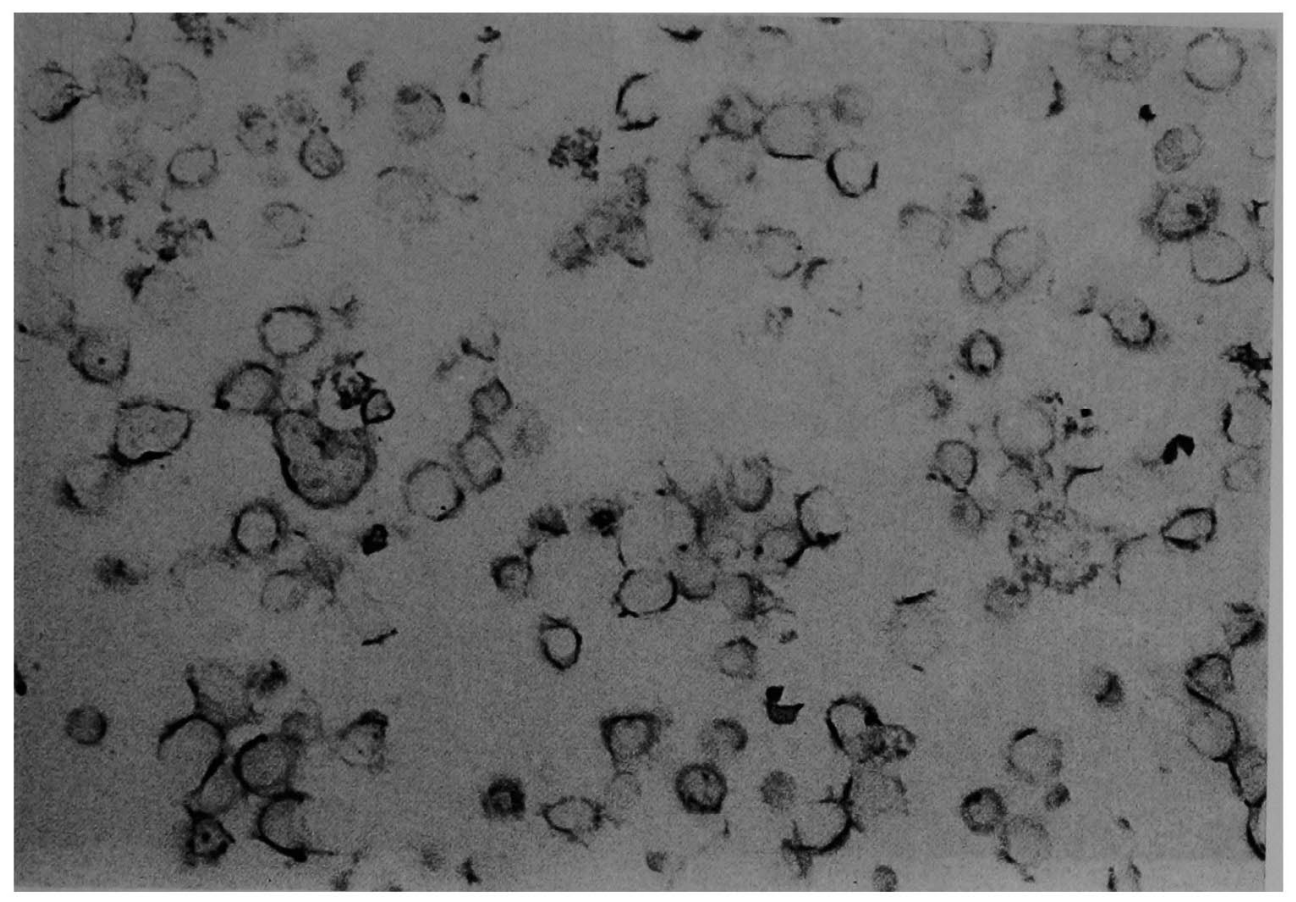

FIG. 2. In situ hybridization of sulfonated v-myc $(990 \mathrm{bp})$ to the paraffin section of cultured HL 60 cells with hematoxylin counter staining. About half the number of HL 60 cells show diffuse cytoplasmic stainings, but the remainders give no visible staining. The diversity of staining pattern from cell to cell implicated the heterogeneity of the individual cell differentiation.

hybridization. Fig. 5 shows the result of Northern blot hybridization for Ha-ras mRNA from 5 of 10 specimens. Increase of oncogene mRNA extracted from the tumor was confirmed by comparison with that from normal mucosa remote from the tumor. Table 1. summarizes the results of in situ hybridization and Northern blot analysis of colorectal cancer.

\section{DISCUSSION}

By the in situ hybridization technique using sulfonated DNA probes, we examined Ha-ras and c-myc oncogene transcription in 2 cell lines and colorectal cancer tissues. NIH/3T3 cells of primary transfectants with T24 Ha-ras gene gave an intense cytoplasmic staining for $\mathrm{v}$-Ha-ras probe. The staining of the individual cells was uniform and all cells showed hybridization by $\mathrm{v}$-Ha-ras probe. Human promyelocytic leukemia cells, HL 60, however, were highly heterogeneous and hybridization by v-myc probe gave a wide range of staining intensities. It has been reported that HL 60 cells are capable of differentiation into granulocytic or monocytic forms by exposure of the cells in culture to various physiological and pharmacological agents $(4,129)$, and the activation and reduction of several oncogenes can occur according 

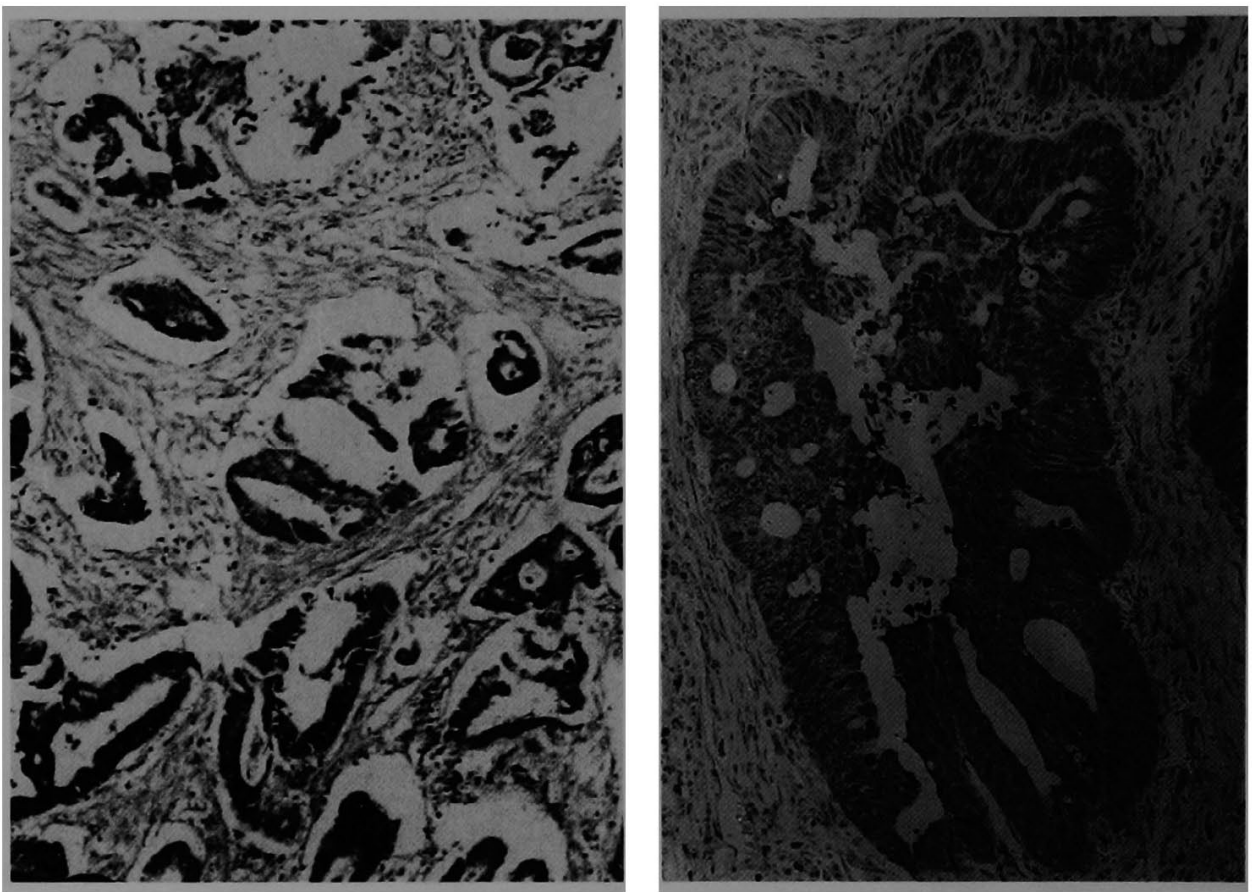

Fic. 3. In situ detection of Ha-ras mRNA of colorectal cancer tissue using sulfonated v-Ha-ras probe. A low power view shows the heterogeneous staining in the section (a), and the specific hybridization is observed at the cytoplasm of cancer cells by high power magnification (b). Counterstained with hematoxylin.

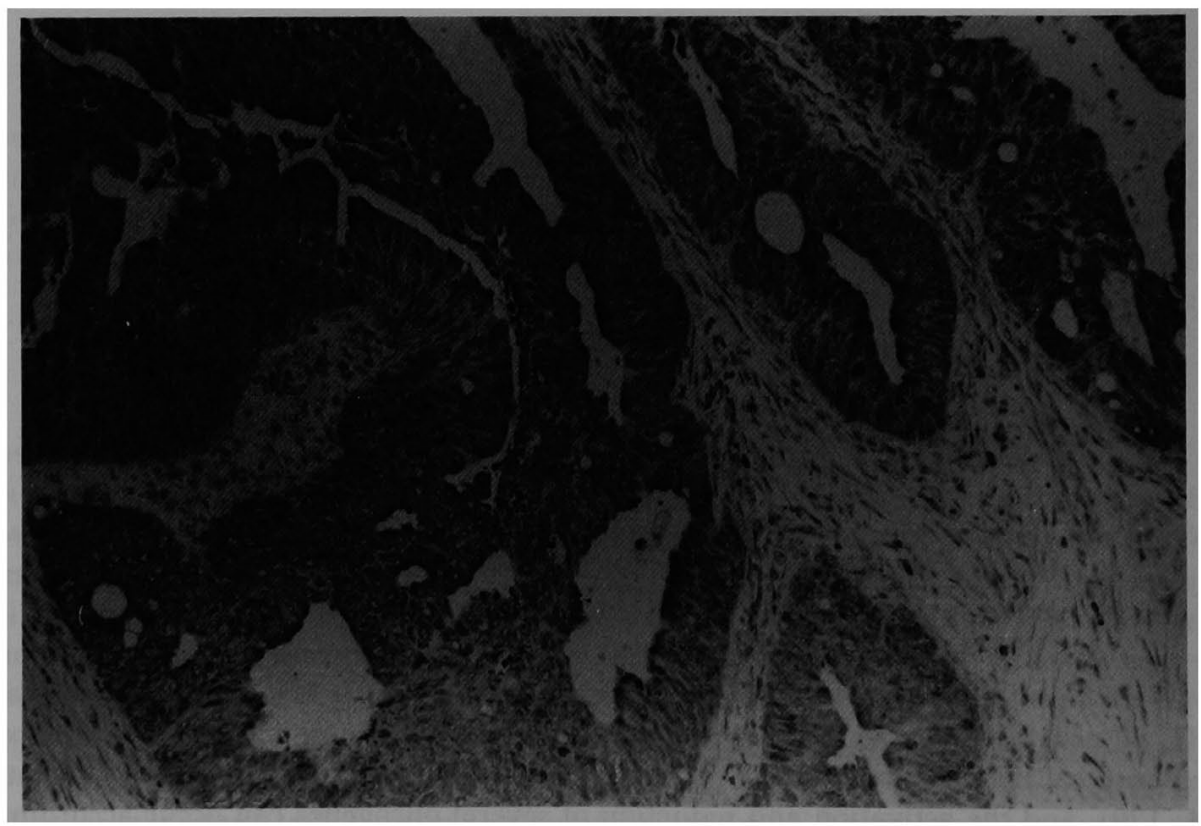

Fig. 4. In situ detection of c-myc mRNA of colorectal cancer. The sulfonated v-myc probe hybridized to cancer cells is clearly demonstrated at the cytoplasm. Counterstained with hematoxylin. 


\section{Northern Blot Analysis(Ha-ras)}

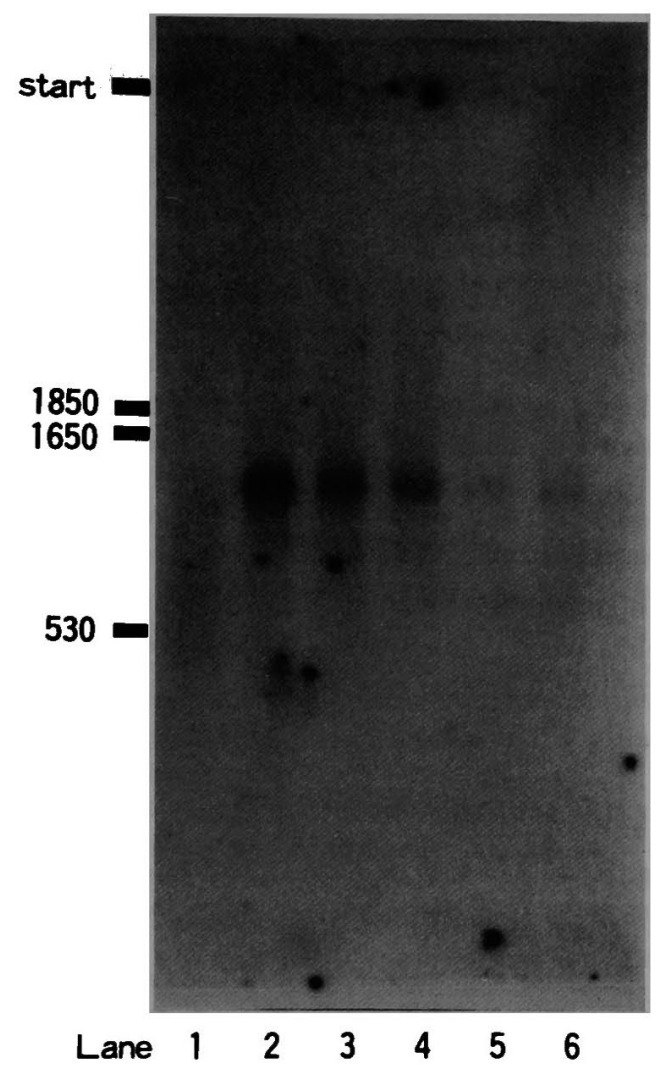

Fic. 5. Northern blots of c-Ha-ras mRNA from colon carcinoma samples (Lane 1-5) and normal colon mucosa (Lane 6). Samples $(5 \mu \mathrm{g})$ of polyadenylated RNAs from tumor tissues and normal mucosa were electrophoresed in $1 \%$ agarose gel and transferred to nitrocellulose, and hybridized by ${ }^{32} \mathrm{P}$-labeled $\mathrm{v}$-Ha-ras probe. Lane 2,3 and 4 give a strong single band at $1.4 \mathrm{~kb}$, and a weak band is observed in lane 1 and 5 as well as in the control lane 6. Lane 1 corresponds to case No. 4, lane 2 to No. 6, lane 3 to No. 3, lane 4 to No. 8, and lane 5 to No. 7 of Table 1 respectively.

to the cell differentiation $(5,25,31)$. The results of our in situ hybridization of HL 60 cells by v-myc probe reflect the potential of differentiation of HL 60 cells in culture.

A survey of colorectal cancer tissue specimens from 24 patients by in situ hybridization disclosed accelerated transcription of Ha-ras gene in 6 and c-myc in 7 . The results of in situ hybridization and those by Northern blot analysis agreed in most cases (see Table 1), but in 3 patients (Table 1, Nos. 6 and 9, Ha-ras; and No. 7, cmyc), Northern blot analysis gave positive band for Ha-ras or c-myc mRNA while in situ hybridization could not identify the positive cells with accelerated transcription of Ha-ras or c-myc gene. The reason for this discrepancy might be the fragility of the 
mRNAs in the tissue blocks, which contained a large amount of RNase which might have digested considerable amounts of RNA in the course of routine processing into paraffin sections (30). Although we took every precaution to minimize the RNase activity by fixing the materials as soon as possible after biopsy and dehydrating them at low temperature, it may be impossible to entirely prevent the RNA from being broken into small fragments.

Another discrepancy between the in situ hybridization and the Northern blot analysis was observed in the specimen from patient No. 4, which was positive for Haras mRNA by in situ hybridization but was negative by Northern blot analysis. In this case, the tumor cells produced copious mucin and the tumor was diagnosed as "mucinous adenocarcinoma" by histology. The sample from such mucinous carcinoma should contain a relatively small number of cancer cells compared to that of normal mesenchymal cells, which might cause the negative band of Ha-ras mRNA by Northern blot analysis.

\section{ACKNOWLEDGMENTS}

We are indebted to Dr. T. Higashi for providing cultured cell lines and Dr. Kimizuka for valuable advice. This work was supported in part by grants-in-aid for scientific research from the Ministry of Education, Science and Culture of Japan.

\section{REFERENCES}

1. Alitalo, K., Bishop, J. M., Smith, D. H., Chen, E. Y., Colby, W. W. and Levinson, A. S.: Nucleotide sequence of the v-myc oncogene of avian retrovirus MC29. Proc. Natl. Acad. Sci. USA 80; 100-104, 1983.

2. Augenlicht, L. H., Augeron, C., Yander, G. and Laboisse, C.: Overexpression of ras in mucus-secreting human colon carcinoma cells of low tumorigenicity. Cancer Res. 47; 3763$3765,1987$.

3. Bos, J. L., Fearon, E. R., Hamilton, S. R., Verlaan-de Vries, M., Boom, J. H., Eb, A. J. and Vogelstein, B.: Prevalence of ras gene mutation in human colorectal cancers. Nature 327; 293-297, 1987.

4. Breitman, T. R., Selonick, S. E. and Collins, S. J.: Induction of differentiation of the human promyelocytic leukemia cell line (HL 60) by retinoic acid. Proc. Natl. Acad. Sci. USA 77; 29362940, 1980.

5. Brelvi, Z. S., Christakos, S. and Studzinski, G. P.: Expression of monocyte-specific oncogenes c-fos and c-fms in HL 60 cells treated with vitamin $\mathrm{D}_{3}$ analogs correlates with inhibition of DNA synthesis and reduced calmodulin concentration. Lab. Inv. 55; 269-275, 1986.

6. Budowsky, E. I., Sverdlov, E. D. and Monastyrskaya, G. S.: New method of selective and rapid modification of the cytidine residues. FEBS Letter 25; 201-204, 1972.

7. Calabretta, B., Kaczmarek, L., Ming, P.-M. L., Au, F. and Ming, S.-C.: Expression of cmyc and other cell cycle-dependent genes in human colon neoplasia. Cancer Res. 45; 60006004, 1985.

8. ' Chesa, P. G., Retting, W. J., Melamed, M. R., Lloyd, J. O. and Niman, H. L.: Expression of p21 ras in normal and malignant human tissues: Lack of association with proliferation and malignancy. Proc. Natl. Acad. Sci. USA 84; 3234-3238, 1987.

9. Chirgwin, J. M., Przybyla, A. E., MacDonald, R. J. and Rutter, W. J.: Isolation of biologically active ribonucleic acid from sources enriched in ribonuclease. Biochemistry 18; 5294-5299, 1979. 
10. Ciclitira, P. J., Macartney, J. C. and Evan, G.: Expression of c-myc in non-malignant and pre-malignant gastrointestinal disorders. J. Pathol. 151; 293-296, 1987.

11. Collins, S. and Groudine, M.: Amplification of endogeneous myc-related DNA sequences in a human myeloid leukaemia cell line. Nature 298; 679-681, 1982.

12. Collins, S. J., Ruscetti, F. W., Gallagher, R. E. and Gallo, R. C.: Terminal differentiation of human promyelocytic leukemic cells induced by dimethylsulfoxide and other polar compounds. Proc. Natl. Acad. Sci. USA. 76; 2458-2462, 1978.

13. Ellis, R. W., DeFeo, D., Maryak, J. M., Young, H. A., Shih, T. Y., Chang, E. H., Lowry, D. R. and Scolnick, E. M.: Dual evolutionary origin for the rat genetic sequences of Harvey murine sarcoma virus. J. Virology 36; 408-420, 1980.

14. Evan, G., Lewis, G. K., Ramsay, G. and Bishop, J. M.: Isolation of monoclonal antibodies specific for human and mouse c-myc proto-oncogene products. Mol. Cell. Biol. 5; 3610-3616, 1986.

15. Gallick, G. E., Kurzrock, R., Kloetzer, W. S., Arlinghaus, R. B. and Gutterman, J. U.: Expression of p21 in fresh primary and metastatic human colorectal tumos. Proc. Natl. Acad. Sci. USA 82; 1795-1799, 1985.

16. Hand, P. H., Thor, A., Wunderlich, D., Muraro, R., Caruso, A. and Schlom, J.: Monoclonal antibodies of predefined specificity detect activated ras gene expression in human mammary carcinomas. Proc. Natl. Acad. Sci. USA 81; 5227-5231, 1984.

17. Hand, P. H., Vilasi, V., Thor, A., Ohuchi, N. and Schlom, J.: Quantitation of Harvey ras p21 enhanced expression in human breast and colon carcinomas. JNCI. 79; 59-65, 1987.

18. Kerr, I. B., Lee, F. D., Quintanilla, M. and Balmain, A.: Immunocytochemical demonstration of p21 ras family oncogene product in normal mucosa and in premalignant and malignant tumour of the colorectum. Br. J. Cancer 52; 695-700, 1985.

19. Lehrach, H., Diamond, D., Wozney, J. M. and Boedtker, H.: RNA molecular weight determinations by gel electrophoresis under denaturing conditions, a critical reexamination. Biochemistry 16; 4743-4751, 1977.

20. McCoy, M. S., Toole, J. J., Cunningham, J. M., Chang, E. H., Lowy, D. R. and Weinberg, R. A.: Characterization of a human colon/lung carcinoma oncogene. Nature 302; 79-81, 1983.

21. Meltzer, S. J., Ahnen, D. J., Battifora, H., Yokota, J. and Cline, M. J.: Protooncogene abnormalities in colon cancers and adenomatous polyps. Gastroenterology 92; 1174-1180, 1987.

22. Morimoto, H., Monden, T., Shimano, T., Higashiyama, M., Tomita, N., Murotani, M., Matsuura, N., Okuda, H. and Mori, T.: Use of sulfonated probes for in situ detection of amylase mRNA in formalin-fixed paraffin sections of human pancreas and submaxillary gland. Lab. Inv. 57; 737-741, 1987.

23. Rothberg, P. G., Spandorfer, J. M., Erisman, M. D., Staroscik, R. N., Sears, R. N., Petersen, R. O. and Astrin, S. M.: Evidence that c-myc expression defines two genetically distinct forms of colorectal adenocarcinoma. Br. J. Cancer 52; 629-632, 1985.

24. Sikora, K., Chan, S., Evan, G., Gabra, H., Markham, N., Stewart, J. and Watson, J.: Cmyc oncogene expression in colorectal cancer. Cancer 59; 1289-1295, 1985.

25. Studzinski, G.P. and Brelvi, Z.S.: Increased expression of oncogene c-Ha-ras during granulocytic differentiation of HL 60 cells. Lab. Inv. 56; 499-504, 1987.

26. Suzuki, T., Yanaihara, C., Hirota, M., Iwafuchi, M., Inoue, T., Mochizuki, T., Iguchi, K., Abe, $\mathrm{K}$. and Yanaihara, N.: Immunohistochemical demonstration of c-myc gene product in tumors induced in nude mice by human hepatoblastoma: A study with antiserum to a related synthetic peptide. Biomedical Res. 7; 365-367, 1986.

27. Tanaka, T., Slamon, D. J. and Cline, M. J.: Efficiency of generating antibodies to oncoproteins using synthesized peptide antigens. Proc. Natl. Acad. Sci. USA 82; 3400-3404, 1985.

28. Tanaka, T., Slamon, D. J., Battifora, H. and Cline, M. J.: Expression of p21 ras oncoproteins in human cancers. Cancer Res. 46; 1465-1470, 1986. 
29. Thor, A., Ohuchi, N., Hand, P. H., Callahan, R., Weeks, M. O., Theillet, C., Lidereau, R., Escot, C., Page, D. L., Vilasi, V. and Schlom, J.: Ras gene alterations and enhanced levels of ras p21 expression in a spectrum of benign and malignant human mammary tissues. Lab. Inv. 55; 603-615, 1986.

30. Tournier, I., Berneua, D., Poliard, A., Schoevaert, D. and Feldmann, G.: Detection of albumin mRNAs in rat liver by in situ hybridization: Usefulness of paraffin embedding and comparison of various fixation procedures. J. Histochem. Cytochem. 35; 453-459, 1987.

31. Watanabe, T., Sariban, E., Mitchell, T. and Kufe, D.: Human c-myc and N-ras expression during induction of HL-60 cellular differentiation. Biochem. Biophys. Res. Comm. 126; 999$1005,1985$.

32. Williams, A. R. W., Piris, J., Spandidos, D. A. and Wyllie, A. H.: Immunohistochemical detection of the ras oncogene p21 product in an experimental tumour and in human colorectal neoplasms. Br. J. Cancer 687-693, 1985. 